\title{
Rebuilding Sudan's health system: opportunities and challenges
}

The power-sharing agreement between Sudan's military and opposition groups signed in July, 2019, marked the end of nearly three decades of military dictatorship, and brought genuine hope of a lasting peace. As of January, 2020, negotiations continue between the transitional government and rebel groups, and the path towards permanent civilian rule is uncertain. Meanwhile, the country faces an escalating humanitarian catastrophe, with 7.8 million people facing critical problems related to mental and physical wellbeing, including 1.6 million internally displaced people and 1.1 million refugees. ${ }^{1} 58 \%$ of the population cannot afford a daily food basket and $26 \%$ do not have access to safe drinking water. ${ }^{1}$ Resources are scarce, economic output having collapsed by two-thirds between 2017 and 2018, ${ }^{2}$ and the country's health system is ill-equipped to respond to growing and neglected needs. While the immediate priority is to secure a lasting foundation for peace, urgent action is needed to address the most pressing threats to population health. Once in place, Sudan must take the first steps in a longer-term programme of health-system reform.

As the UN's latest Humanitarian Needs Overview for Sudan ${ }^{1}$ shows, Sudan's health challenges are considerable. Essential medicines are accessible in only $43 \%$ of health facilities, while only $33 \%$ of health facilities can provide all main components of primary care, with services particularly limited in conflict zones such as Darfur, South Kordofan, and Blue Nile. ${ }^{1}$ Between 2018 and 2019, only 51\% of pregnant women received the minimum of four ante-natal care visits, and just $23 \%$ of deliveries took place in a health facility. ${ }^{1}$ Maternal and infant mortality rates are among the highest in the world, at 311 per 100000 livebirths and $51 \cdot 2$ per 1000 livebirths, respectively. ${ }^{3}$ Immunisation coverage is poor, and infectious diseases, which affect up to $25 \%$ of the population each year, are a particular threat in areas affected by flooding. ${ }^{1}$ In the past 2 years there have been outbreaks of dysentery, typhoid, cholera, chikungunya virus, Rift Valley fever, and dengue. ${ }^{1}$

The former military regime pursued a policy of privat-isation, giving rise to corruption, fragmented financing and the stagnation of the public health-care system. ${ }^{4}$ The legacy is omnipresent. In 2014, spending on health care accounted for $6.5 \%$ of Sudan's national income but only $8.2 \%$ of government expenditure. ${ }^{5}$ Before the dictatorship began in 1989, health care was provided largely free of charge in governmental facilities. The introduction of extensive copayments has pushed up levels of out-of-pocket spending on health care, which reached $73 \cdot 8 \%$ 
of total health-care spending by 2016, a $40 \%$ increase since $2009 .{ }^{2}$ The National Health Insurance Fund (NHIF), launched in 1995, was intended to provide access to basic health services through a country-wide network of service outlets and pharmacies, but coverage had only reached $37 \cdot 3 \%$ of the population by $2014 .{ }^{5}$ Meanwhile, supply shortages and high prices mean that essential medicines are inaccessible for most people ${ }^{1}$. A new health-care funding settlement is needed.

Despite training capacity, including 35 medical scho-ols, Sudan has a shortage of health workers, with only $4 \cdot 1$ physicians and $8 \cdot 3$ nurses and midwives per 10000 population in $2015.6,7$ The workforce has been depleted by severe brain drain, with low staff retention and high emigration of health-care workers driven by poli-tical instability, low wages, and poor quality training oppor-tunities. Over half of Sudanese doctors practise abroad. ${ }^{6}$ Other health workforce challenges include an unbalanced skill mix and inequitable geographical distribution of workers. ${ }^{5}$ Evidently, any plan to rebuild the Sudanese health system must incorporate a long-term and appropriately resourced workforce strategy that covers training and incentives for retention of health-care professionals and administrative staff, combined with the introduction of effective mechanisms for governance and coordination.

The administration of the public health-care system needs to be streamlined. This system is currently managed by the Federal Ministry of Health, the NHIF, the state Ministries of Health, and localities that are inadequately coordinated, giving rise to duplication of responsibilities. A lack of accountability and managerial capacity also pose challenges. ${ }^{4}$ The process of reform should begin with a comprehensive analysis of population health needs and of policy options for the future, including improved methods for collecting taxes and insurance contributions, which will be challenging in a country where the informal sector is estimated to account for as much as $60 \%$ of the economy. ${ }^{8}$ This analysis would need to define a package of benefits to meet essential needs cost effectively and affordably, workforce, supply-chain and infrastructure requirements, and improved mechanisms for data collection and monitoring.

In our view, the obvious future path for Sudan is the introduction of a single-payer national health service. Such a service would build on the present NHIF and use its resources, as well as those of the federal and state Ministries of Health, funded by a combination of general taxation, employer and employee contributions, and regulated by the federal government. International support could help catalyse the required transformation, but Sudan receives low levels of development funding: less than half the average for Africa and the Middle East. 
In 2016 and 2017, Sudan received only \$39 million for health-related development programmes, little of which reached conflict zones in which humanitarian access is a challenge. ${ }^{4}$ The health system's long-term sustainability will ultimately depend on domestic resources.

Sudan's power sharing agreement creates an oppor-tunity for a more representative and pluralistic form of government to take root. Its success will depend on the reconciliation and cooperation of diverse groups that share a difficult history. A new settlement for the provision of health care, as part of a wider programme of state and social reform, could play an important part in healing divisions. Even after the secession of South Sudan, the country remains ethnically diverse, with more than 500 ethnic groups speaking at least 100 languages living within its borders. Whatever the technical solutions to the challenges facing Sudan's health system, inclusivity and the pursuit of social cohesion will be paramount to their success.

We declare no competing interests.

George Wharton, Omar E Ali, Siddiq Khalil, Hatim Yagoub, *Elias Mossialos

e.a.mossialos@lse.ac.uk

Department of Health Policy, London School of Economics and Political Science, London WC2A 2AE, UK (GW, EM); Wayne State University School of Medicine, Detroit, MI, USA (OEA); University of Medical Sciences and Technology, Khartoum, Sudan (SK); and Ahmed Gasim Cardiac and Renal Transplant Center, Khartoum, Sudan (HY)

1 UN. Humanitarian Needs Overview Sudan, January, 2020.

https://reliefweb.int/sites/reliefweb.int/files/resources/Sudan_2020_HNO.pdf (accessed Jan 9, 2019).

2 World Bank. World Bank and OECD national accounts data, Sudan. http://data.worldbank.org/country/sudan (accessed Nov 14, 2019).

3 UN Statistics Division. MDG indicators data. http://mdgs.un.org/unsd/mdg/Data.aspx (accessed Nov 14, 2019).

4 Trithart A. Stuck in crisis: the humanitarian response to Sudan's health emergency. International Peace Institute, April 2019. https://www.ipinst.org/2019/04/stuck-in-crisisthe-humanitarian-response-to-sudans-health-emergency (accessed Nov 27, 2019).

5 Public Health Institute, Federal Ministry of Health. Health system financing review report. Khartoum, Sudan. 2014. 
http://www.phi.edu.sd/IHP\%20book/Health\%20Financing\%20System.pdf (accessed Nov 14, 2019).

6 Abuagla A, Badr E. Challenges to implementation of the WHO Global Code of Practice on International Recruitment of Health Personnel: the case of Sudan. Human Res Health 2016; 14: 26.

7 World Health Organization Eastern Mediterranean Region. Framework for health information systems and core indicators for monitoring health situation and health system performance. Geneva, Switzerland: World Health Organization, 2016. http://applications.emro.who.int/dsaf/EMROPUB_2016_EN_19169.pdf?ua=1\&ua=1 (accessed Nov 14, 2019).

8 Siddig EA, Ismail E. Preliminary development finance assessment for Sudan. UN Development Programme. 2018.

https://www.undp.org/content/dam/unct/sudan/docs/DTF\%20final.pdf (accessed Nov 14, 2019). 